\title{
Exploration on Teaching Management Reform in Applied Undergraduate Colleges under the Full Credit System
}

\author{
Yanan Gou, Wei Xu* \\ College of Mechanical and Electrical Engineering, Zaozhuang University \\ Zaozhuang 277160, China
}

\begin{abstract}
With the development of higher education in China, the implementation of the full credit system has become an inevitable trend of higher education development and reform. It is the fusion product of modern education idea and modern management idea. Firstly, this paper introduces the development course of full credit system, discusses the necessity of implementing the full credit system in applied undergraduate colleges, analyzes the existing problems and constraints of the teaching management under the credit system, and puts forward the reform of teaching management methods and solutions, and provides certain theoretical basis for the implementation of full credit system.
\end{abstract}

Keywords-Full credit system; Applied undergraduate colleges; Teaching management

\section{INTRODUCTION}

The credit system traces its origin to the emergence and development of course selection system. The elective system was first introduced in Germany in the late 18th century. In 1872 , the credit system really became a system that came into force at Harvard University. The mark that China carries out credit system formally is Cai yuanpei implemented the "subject selection system" in Peking University in $1918^{[1][2]}$

Since 1978, there have been four waves of credit system reform. The complete credit system is a teaching management system based on the course selection system, Students can graduate with a certain amount of credits. Academic year and academic year credit system are relative concepts of full credit system. The essence of a full credit system is to modularize knowledge to cultivate students. The credit system has different stages of development. The academic year credit system is a stage of the credit system development, the elective system is the seed of the credit system development, and the developed stage is the full credit system. ${ }^{[3]}$ Under the management system of complete credit system, there will be no professional restrictions (a certain range), no restrictions on the length of schooling (a certain range). Full credit system is a system, which needs more optional courses, wide course setup, free course selection system, free major selection system, tutorial system, perfect student management, charge by credit, point system of academic classification and other hardware and system support. ${ }^{[4]}$ At the present stage, as the scale of higher education is not large enough, higher education has not developed into a "market for students to buy credits", and there are still certain restrictions on the length of schooling. ${ }^{[5][6]}$

\section{THE CHARACTERISTICS OF APPLIED UNDERGRADUATE} COLLEGES AND THE NECESSITY OF IMPLEMENTING FULL CREDIT SYSTEM

The concept of applied undergraduate education was put forward in the 1960s in Europe and America, while in China in the late 1990s. As a new education phenomenon and education type, applied undergraduate education has not been in China for a long time, but it has a highly compatible talent cultivation goal and social demand, and has great development space and potential, which has received widespread attention from colleges and universities. The planning department of the ministry of education has divided the institutions of higher learning into five categories: comprehensive research, single specialty, applied technology, teacher education and vocational skills. Among them, the description of applied undergraduate colleges is that the cultivation of applied undergraduate colleges should serve the regional and industrial development. Through the integration of production and education, schoolenterprise cooperation and the combination of engineering and learning, high-level technical personnel should be trained at the front line of production and service, so as to realize the seamless connection between personnel training and social demands gradually. Applied undergraduate colleges should realize the "triple connection" between professional setting and industrial demand, course content and professional standards, teaching process and production process, and implement the "double certificate" system of academic certificate and vocational qualification certificate, so as to put what they have learned into practice.

Credit system is an important part of modern applied system. The credit system reform can build a teaching management environment suitable for the market economy system and with the market regulation mechanism, so as to efficiently convert social and students demand for education into the power of school education reform, it can timely make adjustment training specifications, major setting, curriculum setting, teaching contents and methods in universities, to meet the needs of students and society. 
Credit system is the institutional guarantee of education in higher education, which is student-oriented and provides personalized education service for students. The systematic characteristics of autonomous course selection, flexible teaching plan, abundant course resources and flexible learning system under the credit system can better meet the requirements of students' independent development than the academic year system, and more conducive to develop various innovative abilities according to the students' own interests and hobbies. The contents of the credit system, such as autonomous course selection, flexible study system, credit calculation and measurement of learning process and achievements, provide the maximum possibility for students to design, manage and control their learning process and activities. This is of special significance to stimulate students' learning initiative, improve students' self-management of learning activities and enhance their creativity in learning activities..

Credit system is helpful to the improvement the comprehensive quality and creative ability of students, it overcomes the disadvantages of traditional education, such as too detailed division of majors and too narrow curriculum coverage, it provides the widest education space for students' learning and development, so students can choose majors, courses and teachers flexibly according to their own learning and development aspirations, and design learning and development plans independently. The credit system also provides conditions for more students to participate in the second class activities. Students who have achieved excellent results in various scientific and technological inventions, innovation contests and other activities can obtain the innovation credits to motivate students to participate in innovative activities and promote the overall development of students' comprehensive quality.

\section{PROBLEMS AND CHALLENGES IN TEACHING MANAGEMENT UNDER THE FULL CREDIT SYSTEM IN APPLIED UNDERGRADUATE COLLEGES}

\section{A. Imperfect teaching management system, backward education management related system}

With the comprehensive development of the credit system, Chinese universities are facing greater challenges. The highly centralized planned economy system in the past has not been completely broken. The credit system reform of Chinese universities is carried out on the basis of the original academic year system. Colleges and universities face many systemic difficulties and development obstacles, such as lack of autonomy in running schools, the relationship between teaching and management and service personnel is unclear, low efficiency of teaching management process, the democratization and scientization of management decisionmaking lack institutional guarantee. Most colleges and universities are gradually changing from the academic year credit system to the complete credit system, the teaching management system is not perfect, and the personnel system, remuneration distribution system, financial management system and student management system are not compatible with the complete credit system. All these make the promotion of complete credit system in colleges and universities received many restrictions.

\section{B. Unreasonable curriculum system and imperfect curriculum construction}

The course selection system is the core of the complete credit system. The implementation of the complete course selection system means that schools should offer a large number of courses for students to choose. However, from the perspective of the course system, the following problems still exist: (1) insufficient flexibility of teaching plan, too small proportion of elective courses, insufficient space for students to select courses, there are too many required courses and students don't have enough free time. The establishment of elective courses ignores the rationality of the curriculum system, which is of little significance to the cultivation of applied talents. (2) The curriculum construction is dominated by theoretical indoctrination, and the classroom teaching still adopts the teacher's active and student's passive teaching methods, which cannot effectively combine the traditional education model with modern teaching methods. The teaching resources are not rich, and the micro class, flipped classroom and online teaching platform have not yet played a great role. (3) The course coverage is narrow, due to the "path dependence" of traditional teaching management system, professional courses are set with clear disciplinary boundaries and excessively detailed professional division, which is not conducive to the implementation of course selection system under the complete credit system, also is not conducive to the cross-integration of professional knowledge and the cultivation of students' comprehensive ability and quality.

\section{Insufficient faculty members and teaching resources}

There is a general shortage of teaching facilities such as education funds, teachers and teaching facilities in universities, which makes them lack the resources and environment to implement the full credit system.

(1) Under the full credit system, course teachers not only need to have a higher professional level and rich education experience, but also need to be able to adapt to the teaching methods and theories in the new mode, which brings great challenges to their education teaching work. The teacher aspect focuses on the problems of small quantity and low quality, which increases the resistance to implement the full credit system. (2) Under the full credit system, schools are required to offer a large number of courses for students to choose, and schools are required to have more classrooms, experimental equipment and other infrastructure. The input of universities in the above aspects is far from enough. Above these "hardware" conditions restricted the development of the complete credit system to some extent. 


\section{METHODS AND MEASURES FOR TEACHING MANAGEMENT REFORM IN APPLIED UNDERGRADUATE UNIVERSITIES UNDER THE FULL CREDIT SYSTEM}

\section{A. Change education teaching philosophy in combination with school features}

The complete credit system is an innovation of the teaching management system, and the implementation of the complete credit system is a systematic project, which is an important measure involving overall situation. Applied undergraduate colleges and universities, therefore, must firmly grasp the complete credit system in the macroscopic direction of reform ideas, to establish "people-oriented" education philosophy, completely abandoned the traditional ideological shackles of university education teaching and management, constantly improve the entire school teachers and students the purpose and significance of the complete credit system reform, operation mode and the understanding of the requirements, strengthen the propaganda of complete credit system, not only in the school, but also for the enterprises and institutions, talent market promotion, complete credit system to carry out smoothly complete credit system create a good internal and external environment.

\section{B. Optimize the teaching management system, set up the credit system reform platform}

1) Establish a teaching management system that is appropriate to the credit system.

The freedom to select courses increases the difficulty of teaching management and the responsibility of teaching management. Schools should establish efficient and easily accepted teaching links by students. Schools should regulate the management of students' status, the course selection system, the different course Settings in each semester, and the supervision and feedback of teaching quality, all departments should coordinate and cooperate with each other, establishing a full credit system teaching management organization and implementation of system, increasing the financial input in teaching of basic facilities construction, establishing the policies and measures matching with full credit system, to provide more effective support for the implementation of the full credit system and guarantee.

\section{2) Make scientific instructional plans and optimize the} curriculum

Reasonably set teaching content and course structure. A reasonable teaching plan is the foundation of a successful credit system. Colleges and universities must set the elective courses of each major according to the training goal, and stipulate the course setting, class hours and credits of each subject group, so as to guarantee the systematicness and integrity of students' learning. Formulate flexible teaching plan, limit the number of elective courses and their total scores by modules and terms. Schools should reduce the class hours of compulsory courses, increase the proportion of elective courses, and divide the courses into multiple modules that are suitable for the full credit system.

\section{Strengthen the construction of the teaching staff, use the "tutorial system" for course selection guidance}

After the implementation of the full credit system teaching management, the teacher's class hours are increased, the difficulty of teaching is increased, and the pressure is increased. Teachers are required to constantly update and enrich their course knowledge, continuously learn the frontier knowledge of the subject, introduce the latest achievements of the subject field to students, and attract students to select courses. In this regard, schools should constantly improve the level of teachers and set a series of incentives. To encourage the young and middle-aged excellent teachers to stand out through the evaluation of excellence, student evaluation of teaching, lecture competition and courseware making competition. Invite famous domestic experts to give professional lectures for teachers, and constantly improve teachers' professional quality and teaching quality. The tutorial system is another feature of the credit system. To realize the "teaching according to one's aptitude", the credit system must implement the tutorial system, which should not only show students' individuality, but also cultivate professional talents with complete knowledge structure. The tutor instructs the students to select courses in a rational and planned way, it can enhance students' rationality in choosing courses and promote the development of professional personnel training. At the same time, schools should also adjust and improve the teacher assessment system. In order to improve the enthusiasm of teachers, schools can try to incorporate the reform effect of the full credit system into the teacher assessment system, so as to break through the current difficulties of the full credit system and promote the further reform of it. This can encourage teachers to constantly innovate their teaching concepts, improve their teaching methods, improve their education teaching level, and eventually cultivate a group of excellent teachers, thus creating favorable conditions for the in-depth development of the full credit system.

\section{CONCLUSION}

To sum up, the emergence of the full credit system has adapted to the needs of the society for talent cultivation, and embodied great advantages in the process of talent cultivation. It is helpful for teachers to teach students according to their aptitude, and is conducive to the development of students' personality and innovation ability, which is the direction of China's college reform. Under the full credit system, the applied undergraduate colleges and universities teaching management reform is imminent, however, no matter how to reform, schools should proceed from the actual situation of themselves, embody the teaching philosophy of peopleoriented, individualized teaching, comprehensive cultivation and improvement of quality, carry out the reform in a planned and systematic way, so that the teaching in colleges and universities will shift from teaching-oriented to learningoriented and finally achieve the purpose of teaching and educating. 


\section{REFERENCES}

[1] Hou Airing, J. Complete credit system and applied personnel training. Jiangsu higher education. 6(2014):90-92.

[2] Li Keyi, Liu Hongmei,Han Yongping,Ge Xizhen,J. Teaching reform ideas and exploration under the full credit system. Education teaching Forum. 10,40(2016):98-99.

[3] Suo Mingjian, Fan Zhe, Liu Qing,J. Try to analyze the reform ideas of credit system teaching management in colleges and universities. Chinese adults education.15(2014):142-143.

[4] Yang Xia,Zuo Hejun, Zhang Yongliang, Zhang Wuwen,J. Probe into the reform path of credit system teaching.Journal of Hulunbeier University.1,26(2018):137-140.

[5] Xu Zhongbing,Xu Jinhua,J. Thoughts on the teaching management of colleges and universities under the complete credit system. Journal of HeBei normal university.11,2(2009):90-93.

[6] Xia Bin, Tang Xiao,J. Mending the Pace of Innovating Credit System and Promoting the Quality of Talent Cultivation. Education teaching forum.28,7(2017):102-103. 